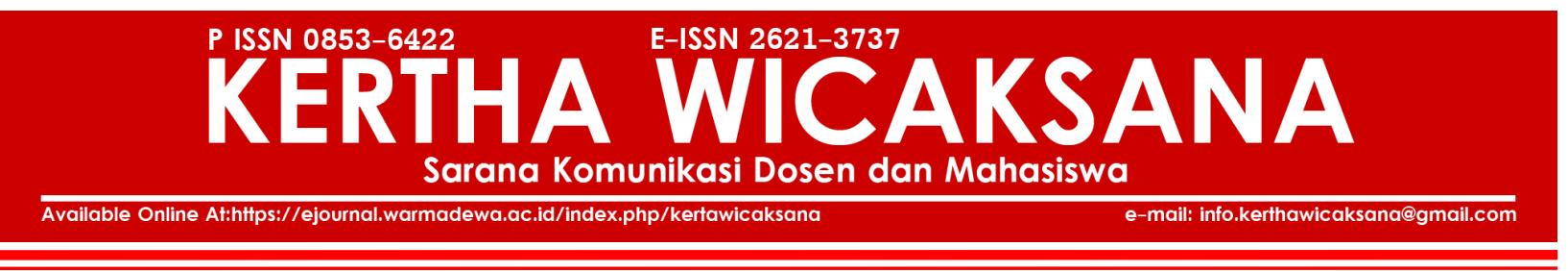

\title{
Kebijakan Hukum Terhadap Penanganan Pandemi Covid-19 di Indonesia
}

\author{
Putu Sekarwangi Saraswati \\ Fakultas Hukum Universitas Mahasaraswati Denpasar, Bali-Indonesia \\ sekarwangisaraswati@gmail.com
}

Published: 30/07/2020

\section{How To Cite:}

Saraswati, P. S. (2020). Kebijakan Hukum Terhadap Penanganan Pandemi Covid-19 di Indonesia. KERTHA WICAKSANA: Sarana Komunikasi Dosen dan Mahasiswa. 14(2). Pp 147-152. https://doi.org/10.22225/ kw.14.2.1923.147-152

\begin{abstract}
Abstrak
Pandemi Covid-19 telah menjadi sangat berbahaya karena menular begitu cepat dan menyebabkan kematian banyak nyawa di dunia. Pemerintah dan Badan Nasional Penanggulangan Bencana telah berkoordinasi dengan pemerintah daerah untuk melakukan penanggulangan bencana dengan menerbitkan kebijakan social distancing maupun physical distancing. Kebijakan PSBB banyak yang kurang efektif karena pasti masyarakat merasa bahwa belum sepenuhnya mendapatkan perlindungan hukum atas kebijakan yang ada yang dibuat oleh pemerintah saat ini. Untuk menghindari tingkat kefatalan lainnya, berikut upaya yang dilakukan agar kebijakan PSBB yang diberikan selama masa pandemi efektif sesuai UUD NRI Tahun 1945 antara lain Pemerintah Pusat dan Pemerintah Daerah memastikan keterbukaan informasi publik secara nyata untuk dapat mengetahui rantai penyebaran virus tersebut. Pemerintah harus dapat menjamin dan memastikan terutama kepada kaum menengah ke bawah mampu memenuhi kebutuhannya untuk menjamin hak atas hidup masyarakatnya dan tidak terkurangi suatu apapun harkat martabat masyarakatnya (sesuai amanat UUD NRI Tahun 1945) dan perlunya peran publik dalam hal saling menjaga, saling mengingatkan, dan saling membantu satu sama lain. Artikel ini selanjunya akan dibahas dengan menggunakan pendekatan kepustakaan dimana penulis akan menggunakan sumber primer berupa buku-buku literature yang ada hubungannya dengan permasalahan yang akan dibedah. Hal-hal yang terjadi di lapangan terlihat bahwa kebijakan hukum yang diputuskan oleh pemerintah dalam masa pandemic covid-19 ini ternyata belum dapat dilaksanakan dengan baik sebagaimana yang diamanatkan karena masyarakat masih banyak yang melanggar dalam kegiatan PSBB yang dicanangkan oleh pemerintah walaupun sanksi pidana telah diatur dengan sangat jelas.
\end{abstract}

Kata Kunci: Kebijakan Hukum, Covid 19, PSBB

\begin{abstract}
The Covid-19 pandemic has become very dangerous because it is transmitted so quickly and caused the death of many lives in the world. The Government and the National Disaster Management Agency have coordinated with local governments to carry out disaster management by issuing social distancing and physical distancing policies. Many PSBB policies are ineffective because surely the community feels that they have not yet fully received legal protection for the existing policies made by the government at this time. To avoid another level of infertility, the following efforts were made so that the PSBB policy provided during the effective pandemic period in accordance with the 1945 Constitution of the Republic of Indonesia, among others, the Central Government and Regional Governments ensures the disclosure of public information in order to be able to find out the chain of the virus spreading. The government must be able to guarantee and ensure especially to the lower middle class are able to meet their needs to guarantee the right to life of their people and not diminished any dignity of the people (in accordance with the mandate of the 1945 Constitution of the Republic of Indonesia) and the need for a public role in terms of mutual care, mutual reminding, and help each other. This article will continue to be discussed using a literature approach in which the writer will use primary sources in the form of literature books that have to do with the problems to be examined. The things that occur in the field can be seen that the legal policy decided by the government during the pvidemic co-19 period has apparently not been implemented properly as mandated because there are still many people who violate the PSBB activities proclaimed by the government even though criminal sanctions have been regulated by very clear.
\end{abstract}

Keywords: Legal Policy, Covid 19, PSBB 


\section{PENDAHULUAN}

Virus corona sampai saat ini masih menjadi musuh terbesar Negara-negara di dunia termasuk Indonesia. Angka peningkatan jumlah kasus corona terus bertambah dengan hasil beberapa melaporkan kesembuhan tetapi tidak sedikit yang dilaporkan meninggal dunia. Berbagai usaha penanganan dan juga pencegahan terus dilakukan demi melawan COVID-19 ini yang gejalanya hampir menyerupai dengan penyakit flu.

Penyebaran COVID-19 ini diketahui melalui penyakit misterius yang awalnya melumpuhkan kota Wuhan, China yang terjadi pada tahun 2019. Tragedy ini terus berlanjut hingga penyebaran virus Corona mewabah ke seluruh dunia. Situs berita CNN melaporkan berikut beberapa hal yang wajib diketahui seputar perkembangan Coronavirus, yang biasa disebut virus Corona atau COVID-19, hingga mewabah dan jadi pandemi.

Gejala awal virus Corona atau COVID-19 dimulai dengan pneumonia atau radang paru-paru misterius pada Desember 2019. Kemudian kasus ini diduga berkaitan dengan pasar hewan Huanan di Wuhan yang menjual berbagai jenis daging binatang, baik yang layak dikonsumsi sampai yang tidak biasa dikonsumsi seperti kelelawar, ular dan tikus dengan berbagai jenisnya.

Pada pasar hewan tersebut ditemukan lah banyak kasus infeksi pneumoni. Selanjutnya diduga Virus COVID-19 dibawa oleh kelelawar dan hewan lain yang selanjutnya dimakan manusia hingga terjadi penularan. Corona virus ini sesungguhnya tidak asing dalam dunia kesehatan hewan, tapi tidak semua jenis hewan yang mampu menginfeksi manusia dengan virus ini hingga menjadi penyakit radang paru.

Seperti yang diketahui bahwa wabah SARS dan MERS lebih dahulu menghebohkan dunia sebelum COVID-19 muncul yang mana kedua wabah tersebut juga berkaitan dengan virus corona. Dilihat dari hal tersebut maka dapat dikatakan virus korona ini bukan kali ini saja mengkhawatirkan warga dunia. Disebabkan gejala yang sama dengan penyakit flu membuat virus korona ini cepat berkembang hingga mengakibatkan infeksi lebih parah dan gagal organ.

Presiden Jokowi pada tanggal 31 Maret 2020 menggelar konferensi pers dengan maksud menyampaikan pengumuman kepada masyarakat perihal kebijakan yang dipilihnya guna menyikapi COVID-19 sebagai pandemi global yang sedang dihadapi oleh masyarakat Indonesia saat ini. Presiden Jokowi memberikan pernyataan bahwa kebijakan Pembatasan Sosial Berskala Besar (PSBB) merupakan kebijakan yang akan diterapkan dalam merespon adanya kedaruratan kesehatan. UU No.6 Tahun 2018 tentang Kekarantinaan Kesehatan menjadi dasar hukum dari adanya kebijakan antisipatif tersebut.

PSBB dapat diartikan sebagai tindakan pembatasan kegiatan tertentu yang fokusnya adalah penduduk dalam suatu wilayah yang dianggap sebagai zona merah atau wilayah yang diduga terinfeksi Corona Virus Disease 2019 (COVID19) dengan sedemikian rupa bertujuan untuk mencegah kemungkinan meluasnya penyebaran Corona Virus Disease 2019 (COVIDI9).

Peningkatan jumlah pasien yang terjangkit covid-19 ini membuat dunia mengeluarkan berbagai kebijakan dalam rangka mencegah virus ini semakin menyebar, termasuk pemerintah Indonesia yang membuat berbagai kebijakan dengan maksud untuk dapat menyelesaikan kasus Covid-19, salah satunya adalah dengan cara mensosialisasikan gerakan Social Distancing atau masyarakat menyebutnya dengan \#dirumahaja ramai digaungkan di media sosial seperti instagram dan twitter.

Berdasarkan uraian permasalahan yang dijabarkan diatas maka penulis merasa perlu untuk membahas lebih lanjut mengenai bagaimana kebijakan hukum terhadapa penanganan pandemic covid-19?

\section{METODE}

Guna membahas permasalahan yang menjadi suatu objek penelitian peranan metodologi sangatlah penting, agar dapat dipertanggung jawabkan akan kebenaran dari suatu fakta yang diamati dan diselidik. Pendekatan yang digunakan dalam jurnal ini adalah berdasarkan pada pendekatan kepustakaan. Bahan-bahan yang digunakan bersumber dari bahan primer yaitu buku-buku literatur yang ada hubungannya dengan penulisan/penelitian ini, dimana bahan primer ini bersifat autoritatif, dalam arti mempunyai otoritas. Disamping itu akan melihat bahan sekunder berupa semua publikasi hukum yang bukan merupakan dokumen resmi, seperti buku-buku teks, jurnal hukum atau komentar atas keputusan pengadilan (Marzuki, 2016). 


\section{HASIL DAN PEMBAHASAN}

\section{Kebijakan Hukum Terhadap Penanganan Pandemi Covid-19}

Berbicara mengenai kebijakan atau yang sering juga disebut dengan Policy yang merupakan sebuah instrument pemerintah, tidak saja dalam arti government yang hanya menyangkut aparatur Negara tetapi juga governance yang menyentuh pengelolaan sumber daya public. Pada intinya kebijakan adalah keputusan-keputusan atau pilihan-pilihan tindakan yang secara langsung mengatur pengelolaan dan pendistribusian sumber daya alam, finansial, dan manusia demi kepentingan public (Suharto, 2008).

Tidak sedikit ahli yang memberikan pendapat mengenai kebijakan public, dari sekian banyak pendapat tersebut apabila ditelaah hampir sebagian besar ahli mengaitkan kebijakan public dengan keputusan ataupun ketetapan pemerintah untuk melakukan suatu tindakan yang dianggap akan membawa dampak kearah yang lebih baik dengan tujuan agar kehidupan masyarakat juga menjadi lebih baik. Hal ini sejalan dengan apa yang dikemukakan oleh (Dye, 1992), "public policy is whatever governments choose to do or not to do", yang diterjemahkan adalah kebijakan public merupakan segala hal pilihan pemerintah untuk melakukan atau tidak melakukan sesuatu (Anggara, 2014). Sangat luasnya pemikiran ini karena kebijakan public mengatur sesuatu yang tidak dilakukan oleh pemerintah di samping halhal yang dilakukan oleh pemerintah dalam memecahkan masalah public.

Pendapat (Anderson, 2010) mengenai kebijakan public dimana beliau memberikan pendapat "Public policy are those policies devoleped by governmental bodies and officials". Menurut James Anderson kebijakan public merupakan kebijakan yang dapat dikembangkan oleh badan dan pejabat pemerintah (Anderson, 2010). Selain itu (Udoji, 1981) yang merupakan seorang pakar yang berasal dari Nigeria memberikan definisi "An sanctioned course of action addressed to particular problem or group of related problems that affect society at large" yang diartikan adalah suatu tindakan bersangsi yang mengarah pada suatu masalah atau sekelompok masalah tertentu yang saling berkaitan mempengaruhi sebagian besar masyarakat (Wahab, 2015).

Penjelasan mengenai kebijakan public (public policy) juga dikemukakan oleh William N. Dunn yang mana menurut beliau pola ketergantungan yang kompleks dari pilihan-pilihan kolektif yang saling tergantung, didalamnya termasuk juga keputusan-keputusan untuk tidak melakukan suatu tindakan yang dibuat oleh badan atau kantor pemerintah (Dunn, 2003).

Pengertian dari beberapa pakar yang dijabarkan tersebut menimbulkan beberapa implikasi bahwa kebijakan public haruslah :

1. Selalu memiliki tujuan tertentu atau paling tidak berupa tindakan yang berorientasi kepada tujuan;

2. Berisi tindakan atau pola tindakan yang dilakukan oleh para pejabat pemerintah;

3. Mengatur apa yang benar-benar dilakukan oleh pemerintah

4. Bersifat positif yang dalam arti merupakan beberapa bentuk tindakan pemerintah yang berisi suatu masalah tertentu atau mempunyai sifat negative dalam arti merupakan keputusan pemerintah untuk tidak melakukan sesuatu.

5. Berlandaskan pada peraturan perundangundangan yang memiliki sifat memaksa (otoritatif)

Tindakan-tindakan yang dilakukan oleh pemerintah pada hakikatnya merupakan kebijakan public, yang mana tindakan ini baik berupa melakukan sesuatu ataupun tidak melakukan sesuatu yang pada dasarnya harus memiliki tujuan tertentu yang mana harus memperhatikan kepentingan masyarakat di dalamnya. Amara Raksasataya berpendapat kebijaksanaan publik sebagai suatu taktik dan strategi yang diarahkan untuk mencapai suatu tujuan. Hal tersebut menyiratkan bahwa suatu kebijaksanaan haruslah memuat elemen-elemen sebagai berikut (Tangkilisan, 2003):

1. Identifikasi dari tujuan yang ingin dicapai;

2. Taktik atau strategi dari berbagai langkah untuk mencapai tujuan yang diinginkan;

3. Penyediaan berbagai input untuk memungkinkan pelaksanaan secara nyata dari taktik atau strategi.

Kebijakan public memiliki tujuan sebagai perangkat tindakan pemerintah yang dirancang untuk menghasilkan hal-hal tertentu yang pada akhirnya akan memuaskan public karena sesuai dengan harapannya dikarenakan public tersebut 
merupakan konstituen pemerintah. Maka dari itu kebijakan public dianggap sebagai pilihan tindakan yang legal dan sah karena dibuat oleh lembaga yang memiliki legitimasi dalam system pemerintahan. Selanjutnya kebijakan public sebagai hipotesis dari sebab dan akibat. Kebijakan senantiasa bersandar pada asumsiasumsi mengenai perilaku.

Corona virus terdeteksi sebagai sekelompok virus yang sebenarnya menyebabkan penyakit pada mamalia dan burung. Tetapi tidak menutup kemungkinan manusia juga dapat terjangkit virus ini, yang mana pada manusia virus ini akan menyebabkan infeksi saluran pernafasan yang dapat ditafsirkan dari ringan sampai dengan mematikan, mulai dari flu biasa sampai dengan penyakit yang berakibat lebih parah.virus ini adalah virus zoonosis yang menurut para ahli virus ini dapat disebarkan melalu hewan dan manusia. WHO telah melakukan investigasi yang mana hasilnya menunjukan bahwa corona virus ini dapat juga ditularkan dari manusia kepada manusia jadi tidak hanya hewan yang dapat menularkan walaupun pada awalnya virus ini diketemukan pada hewan. Kemudian virus ini diberikan nama berdasarkan proyeksinya yang menyerupai gambar mahkota dipermukaan, dan apabila dilihat secara gramatikal corona dalam bahasa latin dapat diartikan sebagai "hallo" atau "mahkota".

Skema penyebaran virus ini memiliki kesamaan dengan virus yang disebabkan oleh flu pada umumnya yang mana disebabkan oleh hal yang sama yaitu misalnya dari batuk dan juga bersin atau dapat juga disebabkan oleh sentuhan dari orang yang telah terinfeksi terlebih dahulu.

Topic utama diseluruh Negara beberapa bulan belakangan ini adalah virus corona. Corona yang tengah menyerang masyarakat seluruh Negara dengan tidak pandang bulu menurut WHO sebagai Novel Coronavirus (2019-nCov) yang pada awalnya mulai merebak di kota Wuhan, China, yang pertama kali dianggap berasal dari pasar hewan liar dan virus ini terdapat pada hewan yang dapat ditularkan dari hewan ke manusia (zoonosis), dan belakangan diketahui pula dapat menular dari manusia ke manusia. Yang mana cara menularkan virus covid- 19 ini dapat dari cairan saat bersin atau batuk, udara, kontak langsung, hewan dan dekat bahkan dengan pasien yang sudah terjangkit terlebih dahulu. Virus ini membutuhkan waktu berinkubasi paling pendek dua sampai tiga hari dan paling lama dapat mencapai sepuluh hingga dua belas hari. Rentang waktu tersebut dibutuhkan oleh virus untuk menjangkit dan menunjukkan gejala-gejala awal, kemudian dalam lingkup inkubasi ini virus dapat menular ke orang lain yang akan menyebabkan sulitnya dideteksi dengan kasat mata.

Ada beberapa regulasi yang berkaitan dengan penerapan PSBB tersebut. Antara lain adalah PP No. 21/2020 tentang Pembatasan Sosial Berskala Besar Dalam Rangka Percepatan Penanganan Corona Virus Disease 2019 (COVID-19), Peraturan Menteri Kesehatan (Permenkes) Nomor 9 Tahun 2020 tentang Pedoman Pembatasan Sosial Berskala Besar Dalam Rangka Percepatan Penanganan Corona Virus Disease 2019 (COVID -19), dan juga Peraturan Pemerintah Pengganti Undang-Undang (Perpu) Nomor 1 Tahun 2020 tentang Kebijakan Keuangan Negara dan Stabilitas Sistem Keuangan Untuk Penanganan Pandemi Corona Virus disease 2019 dan/atau dalam Rangka Menghadapi Ancaman yang Membahayakan Perkekonomian Nasional dan/ atau Stabilitas Sistem Keuangan.

Status pembatasan social berskala besar dapat ditetapkan apabila suatu wilayah atau provinsi atau kabupaten atau kota memenuhi kriteria yang ditentukan yaitu jumlah kasus dan/atau jumlah tingkat kematian akibat virus ini meningkat secara signifikan dan cepat menyebar ke beberapa wilayah dan kriteria yang berikutnya adalah terdapat kaitan epidemiologis dengan kejadian serupa di wilayah atau negara lain. Secara mekanisme apabila suatu wilayah menampakan kriteria yang disebutkan tersebut maka selanjutnya harus diajukan oleh kepala daerah, baik gubernur/ bupati maupun walikota dengan mengajukan data adanya peningkatan jumlah kasus baik yang terjangkit sampai yang meninggal, adanya peningkatan jumlah penyebaran menurut waktu, serta adanya kejadian transmisi lokal. Kemudian data tersebut haruslah dilengkapi pula dengan adanya kurva epidemiologi yang dapat dibaca dan diartikan telah terjadinya penularan di wilayah tersebut. Selain hal tersebut, dalam mengajukan permohonan PSBB kepala daerah haruslah menyampaikan informasi mengenai bagaimana kesiapan daerah tentang aspek ketersediaan kebutuhan hidup dasar yang nantinya akan diberikan kepada rakyat, sarana prasarana kesehatan, anggaran dan operasionalisasi jaring pengamanan sosial, dan aspek keamanan. 
Muncul berbagai kebijakan yang hendak digunakan untuk memerangi virus ini terkadang menimbulkan kebingungan atau bahkan pro kontra. Di satu sisi adanya upaya yang akan diambil untuk menghambat penyebaran dengan cara mengeluarkan para Napi yang masih berada di dalam penjara, namun di sisi lain malah muncul aturan yang mengancam akan memasukkan ke dalam sel penjara bagi masyarakat yang menjadi pelanggar aturan terkait pencegahan wabah ini. Maka dapat dilihat bahwa aturan ini nyatanya bertolak balik dengan aturan hukum yang lainnya dalam rangka pencegahan penyebaran pandemic Covid-19 ini.

UU No 6 tahun 2018 tentang Kekarantinaan Kesehatan, khususnya pasal 93 memang sudah mengatur tentang aturan bagi pelanggar pembatasan sosial berskala besar (PSBB), selain Pasal 218 KUHP. Hal ini kemudian ditindaklanjuti pemerintah dengan mengeluarkan Peraturan Pemerintah (PP) Nomor 21 tahun 2020 tentang Pembatasan Sosial Berskala Besar (PSBB). Karenanya, saat Peraturan Pemerintah telah resmi dikeluarkan, maka pihak kepolisian sebagaimana amanat Presiden secara tegas melakukan tindakan upaya penegakan hukum bagi pelanggarnya. Artinya, pencegahan wabah pandemi Covid-19 ini harus dilakukan dengan memberikan sanksi pidana bagi warga masyarakat yang melakukan pelanggaran.

Melalui Maklumat Kapolri No. Mak/2/ III/2020 tentang Kepatuhan Terhadap Kebijakan Pemerintah dalam Penanganan Penyebaran Virus Corona, kemudian pihak kepolisian melakukan tindakan mengamankan masyarakat yang tidak mengindahkan himbauan PSBB tersebut, walaupun kemudian sebagian besar dilepaskan kembali. Namun, tentunya bila ketegasan ini ditegakkan akan banyak warga masyarakat yang melanggar menjadi tahanan, yang kemudian secara hukum harus diadili dan dipenjarakan (Yunus, 2020).

Ketentuan pasal 93 Undang-Undang Kekarantinaan Kesehatan telah jelas memberikan ancaman sanksi pidana paling lama 1 (satu) tahun dan/atau pidana denda paling banyak Rp100.000.000,00 (seratus juta rupiah), sedang pada Pasal 218 KUHP dinyatakan adanya ancaman pidana penjara paling lama empat bulan dua minggu atau pidana denda paling banyak sembilan ribu rupiah bagi siapa saja pada waktu rakyat datang berkerumun dengan sengaja tidak segera pergi setelah diperintah tiga kali oleh atau atas nama penguasa yang berwenang.

\section{SIMPULAN}

Berdasarkan pembahasan di atas, maka dapat disimpulkan bahwa Kebijakan Hukum Terhadap Penanganan Pandemi Covid-19 Di Indonesia belum dapat dilaksanakan dengan baik sebagaimana yang diamanatkan dalam peraturan perundang-undangan, karena masih banyak masyarakat yang melanggar dalam kegiatan PSBB. Walapun sudah sangat jelas ada sanksi pidana yang dapat dikenakan bagi yang melakukan pelanggaran. Dengan keadaan yang demikian seharusnya Pemerintah Pusat dan Pemerintah Daerah memastikan keterbukaan informasi publik secara nyata untuk dapat mengetahui rantai penyebaran virus tersebut, dan harus dapat menjamin dan memastikan terutama kepada kaum menengah ke bawah mampu memenuhi kebutuhannya untuk menjamin hak atas hidup masyarakatnya dan tidak terkurangi suatu apapun harkat martabat masyarakatnya (sesuai amanat UUD NRI Tahun 1945) dan perlunya peran publik dalam hal saling menjaga, saling mengingatkan, dan saling membantu satu sama lain.

\section{DAFTAR PUSTAKA}

Anderson, J. A. (2010). Public Policymaking: An Introduction. Wadsworth Cengage Learning. Retrieved from https://books.google.co.id/ books?

id $=$ A3phpKTD1pYC\&printsec $=$ frontcover $\# \mathrm{v}=\mathrm{o}$ nepage \&q\&f=false

Anggara, S. (2014). Kebijakan Publik. Bandung: CV Pustaka Setia.

Dunn, W. N. (2003). Analisis Kebijakan Publik, Terjemahan. Yogyakarta: PT. Hanindita Graha Widya.

Dye, T. R. (1992). Understanding Public Policy. United States of America: Prentice-Hall.

Marzuki, P. M. (2016). Penelitian Hukum Edisi Revisi. Jakarta: Kencana Prenada Media Group.

Suharto, E. (2008). Kebijakan Sosial Sebagai Kebijakan Publik. Bandung: Alfabeta.

Tangkilisan, H. N. S. (2003). Evaluasi Kebijakan Publik. Yogyakarta: Balairung \& Co.

Udoji, C. J. O. (1981). The African Public Servant As Public Policy in Africa. Addis Abeba: African Association For Public Administration and Management.

Undang-Undang Nomor 6 Tahun 2018 tentang Kekarantinaan Kesehatan

Wahab, S. A. (2015). Analisis Kebijakan: dari formulasi ke penyusunan model-model Implementasi Kebijakan Publik. Jakarta: Bumi 
Aksara.

Yunus, N. R. (2020). Kebijakan Covid-19, Bebaskan Narapidana dan Pidanakan Pelanggar PSBB. Adalah: Buletin Hukum \& Keadilan, 4(1), 1-6. Retrieved from http://journal.uinjkt.ac.id/ index.php/adalah/article/view/15262 